\title{
IDEOLOGY AND POLITICAL DISCOURSE: A CRITICAL DISCOURSE ANALYSIS OF PRESIDENT NANA AKUFFO ADDO'S 2018 STATE OF THE NATION ADDRESS
}

\author{
Cynthia Logogye $\mathrm{e}^{\mathrm{i}}$ \\ Department of English Education, \\ University of Education, \\ Winneba, Ghana
}

\begin{abstract}
:
This paper is a critical discourse analysis of the 2018 (SONA)- State of the Nation Address delivered by Ghana's president, Nana Akuffo-Addo. Using van Dijk's (2004) ideological strategies, the study investigates how the president tries to justify his government's ideas and persuades his audience by utilizing subtle ideological discourse structures in his speech. The text used in the study is the whole of the 2018 state of the nation address obtained from www.my joy online.org. The study employs content analysis for analysing the data. The major ideological strategies employed have been positive self-representation and in-group favouritism supported by minor ideological strategies while projecting past opponent governments negatively.
\end{abstract}

Keywords: discourse, critical discourse analysis, political speech, state of the nation address, positive self-representation, negative other-representation

\section{Introduction}

This study is an attempt to critically study the underlying ideologies behind president Nana Addo of Ghana's state of the nation address in order to show a better understanding of the political purpose of that speech.

The political field is thoroughly ideological and so are its political practices, hence one needs to be a skilled communicator to appeal to the various interest groups that political discourse caters for. To preserve the self in a harmonious social order, politicians and political actors use communication tools to rally people behind them (van Dijk, 2006). Since politicians lean towards ideologies and their speech acts reflect their ideological stance, any attempt to make meaning of political discourse must take into consideration the fact that the choices of the political actors will not be ideologically neutral. Political speeches are usually delivered by politicians at political forums. These speeches more often than not are speeches aimed at either a struggle for power or maintenance or control of it. According to Bayram (2010), politics is the

i Correspondence: email clogogye@yahoo.com, clogogye@gmail.com 
field for power struggle, and that politicians engage in the struggle for power in order to implement their political, economic, and social ideas. To this end, in the field of politics, language plays a crucial role; politicians use language as a vital tool to shape the political thoughts of the electorates and to convince them to buy into their ideologies (Bayram ibid).

Chimbarange, Takavarasha, and Kombe (2014) maintain that the main aim of politicians is to persuade their audience of the validity of their political claims. They, therefore, employ linguistic resources that shape the thoughts and behaviour of electorates. As part of their manipulative strategies, they put in efforts to convince the electorates to discard their political ideologies and hold on to theirs.

Due to the well-organized nature and structure of political discourse, political discourse analysis has for a long time gained the attention of scholars as they supply a rich source of discovery about the nature of language manipulation; every political action is conveyed through language. While politicians may be interested in how to gain support from the public, linguists and critical discourse analysts might be interested in the way such support is enacted by language (Reza and Zohre, 2014). Political language rhetoric has therefore been studied from different perspectives and disciplines such as linguistics, anthropology, psychology, communication science, and discourse science. See for instance (Chilton, 1995, 2004; Chilton and Schaffner, 2002; Wilson, 1990; Wodak and Menz, 1990). The interest behind such studies has been on divulging language misuse and the way such misuse has been legalized.

The literature has shown that all over the world, scholars are subjecting political text and talk to vigorous analysis to shed light on the meanings they contain and to identify the bias, prejudice, and true meanings of the political speeches.

This paper aims to identify the ideological strategies within the discourse structures in the 2018 state of the nation address delivered by President Nana Addo of Ghana. Several levels will be observed: semantic macrostructures (topics), local meanings, and strategies especially aimed at positive self-presentation and negative other-presentation in order to explain to what extent the speakers' partisan ideologies are reflected in his linguistic choices. The point that has to be tested is how the speech follows the postulates of the "ideological square" as presented by van Dijk (2004).

\section{Statement of the Problem}

From the literature, popular genres of political discourse that are studied include manifestoes, inaugural addresses, parliamentary debates, and even social media posts as well as other political speeches. (Hemas and Ariyanti, 2016; Kondowe, 2014; Naz et al., 2012; Alvi and Baseer, 2011; Nadashkiska, 2006; Zhao and Zhang, 2017; Farhat, 2016; Michira, 2014; Alvi and Baseer, 2012; Donna Wang, 2010). Works in political discourse in Ghana have mostly focused on speech acts (Sarfo, 2016 and Boakye, 2014), transitivity (Adjei and Ewusi, 2015, 2016), politeness (Ghampson, 2011, Wilson, 2017), and gender representation in politics.

Although much has been done on political discourse, ideology in political discourse and by far, state of the nation address in Ghana has remained under-researched. This article redresses 
the deficit by using critical discourse analysis to analyse the ideological strategies adopted in the delivery of the state of the nation address in Ghana. The state of the nation address appears to be the most popular of all the political genres in Ghana in the sense that there are always controversies after the president has delivered the state of the nation address such that the opposition usually comes out with their own state of the nation which they term 'The True State of the Nation Address.' As politicians, they use this forum to gain support from the public. On the other hand, as linguists, our quest should be on how through language such support is enacted. And this is what the present researcher seeks to do.

The political field is thoroughly ideological, so are its practices, and hence its discourses (Chilton, 1995, 2004; Chilton and Schaffner, 2002; Wilson, 1990; Wodak and Menz, 1990). Every political discourse is embedded with certain ideologies explicitly expressed and formulated (Khany and Hamzelou, 2014). In the words of van Dijk (2006) ideologies represent one of the dimensions of the social identity or self-image of groups. In a similar vein, Iwamoto (2007), is of the view that no discourse is ideologically neutral. This article, therefore, concerns itself with identifying the ideologies conveyed in the state of the nation address in Ghana. I am of the view that to understand political discourse better, one needs to know the identity or self-image of the political group. I, therefore, see it necessary to investigate the ideologies behind the speech made by the president if the citizens have to understand and make meaning of it. I believe understanding the ideologies of political actors will help give a better understanding of their discourses. And, I believe a study of the state of the nation address can be a good starting point.

\section{Aims and Objectives}

This paper attempts to perform a critical discourse analysis of President Nana Akuffo Addo's state of the nation address with the aim of revealing the ideologies he and his government operate and intend to operate. The study tries to realize the following objectives:

1. to uncover the ideologies underlying the speech and unveil his plans and strategies of sustaining power.

2. to show the relationship between politics and ideology.

\section{State of the Nation Address}

Political speeches may be diverse encompassing manifestos, inaugural addresses, state of the nation address, etc. The most popular is the state of the nation address. At the beginning of each session of the Parliament of Ghana, the President has to go to parliament to satisfy the constitutional requirement of delivering to Parliament and the people of Ghana a message on the State of the Nation, that is to report on how the nation is faring and to share the prospects that can be looked forward to in the year ahead and so civil society, as well as political opponents, are always looking up to it to know the state of the nation from the 'the horse's own mouth', the president. Listeners then try to juxtapose what is said and the realities on the ground as well as what to expect in the coming years or plans of the government for the nation in the coming years. 
In this type of speech, the president does not only persuade the citizenry to continue to give his government their support but also tries to build in the electorates confidence and hope in his administration.

Language in this context can be seen as an embodiment of ideologies and at the same time an instrument of persuasion; a tool for controlling and consolidating power and a tool for acquiring power (Sharndama, 2015). Van Dijk (1993) is of the view that political leaders, in such speeches, try to influence the mental models, knowledge, attitudes, and eventually even the ideologies of recipients using language.

In Ghana, the state of the nation address always sparks off controversies between government supporters and the opposition and their supporters such that after the president has delivered the state of the nation address, the opposition also presents what they call "The True State of the Nation Address" This is the reason for which the present study seeks to analyse the underlying ideologies behind Nana Addo's state of the nation address as revealed through the use of language.

This investigation has become necessary since, in recent times, politics in Ghana is becoming a matter of public concern. Civil society is attentive to what politicians do and say including attempts to analyse the implication of what is said. This is as a result of the proliferation of radio and television stations across the country.

As a consequence, people are increasingly becoming aware of the intrigues of politicians. The activities of politicians and what they say are constantly under scrutiny by the public in the media. These days, politicians do not get away with what they say.

The concern for this paper has, however, been based on the question of whether the discourse analysts are aware of the underlying ideologies that form the basis of the discourses they analyse. I believe a knowledge of the ideologies behind political utterances as conveyed through the enactment of language can help clarify the messages, intentions of politicians, and the implication of their speeches appropriately.

This paper hereby seeks to unravel the linguistic strategies used by politicians to convey their political ideologies. According to Iwamoto (2008), no discourse is ideologically neutral. This paper, therefore, concerns itself with identifying the ideological strategies employed by president Nana Akufo Addo in his delivery of the 2018 state of the nation address to parliament and the people of Ghana. I believe that political discourse can best be analysed and interpreted when the ideologies of players in politics are made bare.

\subsection{CDA}

The study employs CDA in identifying the underlying ideological strategies adopted by the president in his delivery of the state of the nation address. It aims at denaturalizing the hidden ideological processes embedded in the address. It seeks to uncover the discursive means of mental control; it also plays a crucial role in awakening people to the ideological strategies of politicians. It seeks to explore how language as a linguistic tool can be manipulated by persons, derived either by good or ill intentions, to persuade other people. 
In essence, this article attempts to examine the relationship between political discourse and ideology more closely using critical discourse analysis as a tool to unmask the ideologies behind the speech of Nana Addo.

CDA is considered useful in the analysis of especially, political discourse because it affords scholars the ability to dissect a discourse, find distortions, go through it and discover the reality for themselves.

Given that purpose, this paper adopts CDA as an aid to discover the underlying ideologies behind the 2018 state of the nation address delivered by president Nana Ado. The study investigates how the president tries to justify his (party's) ideas and persuade his audience by utilizing subtle ideological discourse structures in his speech.

Van Dijk (1998a) sees Critical Discourse Analysis (CDA) as a field that is concerned with studying and analysing written and spoken texts to reveal the discursive sources of power, dominance, inequality, and bias.

CDA, therefore, constitutes an important tool in the analysis of political discourse. It primarily studies the way social power abuse, dominance, and inequality are enacted, reproduced, and resisted through text and talk in a social and political context. In that vein, critical discourse analysts are preoccupied with the zeal to understand, expose, and ultimately resist social inequality (Van Dijk, 1985, cited in Wang, 2010).

CDA has for a long time now proven to be a valuable tool for the analysis of discourse in several fields of study, especially political genre. State of the nation addresses, inaugural addresses, parliamentary discourse, presidential campaigns, and political debates are all the fields of ideological battles. This explains why van Dijk (2004) contends, "it is eminently here that different and opposed groups, power, struggle, and interests are at stake". According to him, political groups, therefore, need to be ideologically conscious and organized to be able to compete. A key factor that determines the success of politicians reaching their goals and winning the public consensus in this continuous power struggle is their ability to persuade and impress their audience. Teittinen (2000, p.1) contends that the winner is a party whose language, words, terms, and symbolic expressions are dominant once reality and the context have been defined. There is therefore the need for critical listening and reading of political discourse to realize what the reality is and to understand the skillful use of language in political genres.

A prominent focus in CDA is the ideological concern and its relation to power (Van Dijk, 2000). In fact, "when we speak or write we always take a particular perspective on what the world is like" (Gee, 1999: 2). In Language in the News, Fowler (1991: 101) said: "anything that is said or written about the world is articulated from a particular ideological position". Ideologies then serve as the basis for constructing the social manifestations of the beliefs shared by a group and foster new social opinions and spread them in society.

O'Halloran (2005: 1946) holds the view that CDA, as an important branch of Discourse Analysis (DA), focuses on relations between ways of thinking and ways of talking, and highlights "the traces of cultural and ideological meaning in spoken and written texts". At this point, Fairclough (1995) contends that CDA includes the larger socio-political and socio-cultural contexts within which discourse is embedded, as it is at this macro-level of analysis that we are able to unpack 
the ideological bases of discourse that have become naturalized over time and are treated as common sense, acceptable and natural features of discourse.

Using the CDA approach in complementation with van Dijk's ideological models, I believe will serve as very useful tools to unravel the main ideological strategies that the speechmaker employs to make the speech effective at persuading the audience in order to win the favour and support of the people and to control power.

In that regard, it is common to see the perception of 'reality' that political speechmakers present in a form that they regard as most suitable for the intended audience and listeners.

\section{Review of Related Literature}

Sharndama (2015) did a critical discourse analysis of the inaugural Speech of President Muhammadu Buhari of Nigeria which was delivered shortly after his swearing into office using Norman Fairclough's three-dimensional Analytical Models. Following the model, the speech was subjected to description, interpretation, and explanation. The result of the analysis showed that Buhari used the inaugural speech to reveal his plans to the people and to instill in them hope in the new government. The speech analysed particularly revealed the ideologies on which the new government headed by President Muhammadu Buhari intends to operate.

Krzyzanowski (2005) examined the various discursive constructions, negotiations, and reformulations of political and institutional identity of the EU within the recently completed European Convention within the discourse-historical framework developed by Ruth Wodak. The study explored characteristics of the EU discourse about the future of Europe by illustrating the discursive realization of the 'mainstream voice' in the European Convention, its dissolution of national standpoints, and the characteristics of discourse from the EU-Candidate countries.

Oberhuber (2005) specifically focused on the phenomenological reality of the European Convention process in the context of the ongoing constitutional debates in Europe. Based on the empirical study, he critically discussed the application of a model of deliberation for describing and interpreting the Convention process and doubted its capacity in grasping the essence of the Convention process. It was argued that deliberation, being inherent to human communication under particular ideal conditions, was not the best solution to interpreting the Convention process.

Khany and Hamzelou (2014) studied the political speeches of some notorious dictators throughout history, Stalin, Gadhafi, and Hitler using a Systemic Functional Grammar approach. 20 speeches were rhetorically analysed. To reveal their disguised intention and disclose their style and structure, their study attempted to decipher generic patterns of the speech. The study revealed that the dictators owed their states to words they used to legalize their misdeeds.

Utilizing Critical Discourse Analysis Theory and Systemic Functional Linguistics Khany and Hamzelou (2014) analysed Barack Obama's presidential speeches mainly from the point of transitivity and modality. The study revealed how the speaker tried to use ideology and power to win the favour of the people. 
Rashidi and Souzandehfar (2015) investigated the ideologies underlying the discursive structures in the speeches of two presidential candidates of two major American political parties (Republican and Democratic) candidates of the US presidential primaries of 2008 on the continuation of the war in Iraq.

Matić (2014) investigated the semantic macrostructures, local meanings, and linguistic devices which were used in the speeches of two American candidates in the 2008 presidential election, especially those aimed at positive self-presentation and negative other-presentation and explained the global and local contextual levels which shape such discourse structures.

Wang (2010) analyzed Barack Obama's presidential speeches mainly from the point of transitivity and modality, to show a better understanding of the political purpose of those speeches. Shakeel (2010) on the other hand investigated the hidden ideologies behind the speech of the prime minister of Pakistan on some key issues related to Pakistan and one most crucial matter, "drone attacks" using critical discourse analysis as a tool to unmask the ideologies behind her speech

Al-Faki (2014) conducted a study on ideology within the political speeches of African Leaders using SFL and other linguistic tools such as modality. The aim was to find out how ideology is embedded in 'political discourses of African leaders. The conclusion drawn was that the Modal auxiliary verbs are used only twice, recording the least linguistic feature the African political discourses embody compared to other several metaphorical and rhetorical devices.

Edu-Buandoh and Ahialey (2012) investigated questioning as an elicitation strategy used by counsels during cross-examination in Ghanaian legal discourse using Discourse Analysis as a methodological tool. Their aim in the paper was to discuss the types and functions of questions used in elicitation during cross-examination of witnesses and defendants by counsels. The results showed that questions in elicitation serve ideological more than informative functions.

In sum, almost all the studies reviewed above investigated ideologies underlying discursive structures especially in political discourse as almost all studies reviewed are conducted on the speeches of political figures using CDA just as the purpose of the present study. What is intriguing about all the findings in the analysis of the political speeches is that critical discourse analysis is capable of unmasking hidden ideologies in political speeches. In essence, the studies reviewed serve as a guide to the present study as it seeks to identify the hidden ideologies in the 2018 SONA presented by president Nana Addo of Ghana.

\section{Politics and Ideology}

Politics is one of the social domains whose practices are virtually exclusively discursive; political cognition is by definition ideologically based, and political ideologies are largely reproduced by discourse (van Dijk, 2006). Depending on one's view of the world, ethics, or group affiliation, a group's ideas may be valued positively, negatively, or not be valued at all.

Different forms of government utilize ideology in various ways. The practice of politics has over the years been full of the tactful formulation of perceptions and beliefs about significant occurrences, of problems, of policy changes, and mostly of leaders. Amidst the construction of 
beliefs are issues of interests, persuasion, and manipulation, imposition of opinions, the definition of allies and opponents, etc. In so doing, language plays a crucial role in revealing the communicative implications in the discourse of politics. Edelman (1985, p1) attests to this phenomenon when he comments thus, "While coercion and intimidation help to check resistance in all political systems, the key tactic must always be the evocation of meanings that legitimize favoured courses of action and threaten or reassure people to encourage them to be supportive or remain quiescent".

This evocation of meanings more often than not hinges on carefully crafted speeches which become an integral component of the field of politics. This is mostly based on intended objectives, to persuade the audience to accept the position of the speaker. To this end, political speeches assume traits such as subtle mystification and distortion in their quest to persuade the audience to accept the stance of the speaker (Edelman, 1985). In the struggle for political power between those who seek to assert and maintain power, and those who seek to resist it, for instance, the ability of a political speech to mystify and distort becomes very crucial.

Political actors therefore often use speech to influence or change the choices, thoughts, and responses of the electorates towards their ideas, issues, concepts, or products (Hemas and Ariyanti, 2015).

Van Dijk's (2004) ideological strategies were adopted as the framework to detect the discursive structures within the transcripts of the candidates. Their study discovered that the macro strategies of 'positive self-representation and 'negative other- representation' (which are intimately tied up with 'Polarization' of in-group vs. out-group ideologies or US-THEM) plus the other 25 more subtle strategies have turned out to be very accurate criteria for the evaluation of attitudes, and opinions.

\title{
6.1 Theoretical Background
}

In politics, ideologies play a role to define political systems, political practices, and political cognition, all enacted or reproduced by political discourse (van Dijk, 2004). Krugman (2015) is of the view that underlying political ideologies are typically expressed in political discourse by emphasizing Our good things and their bad things, and by de-emphasizing Our bad things and their good things. Such a general strategy may be implemented at all levels of political discourse. The framework adopted in this study is that of van Dijk's (2004) ideological strategies supported by CDA. This framework consists of two main discursive strategies of 'positive selfrepresentation or in-group favouritism; a semantic macro- strategy used for the purpose of 'face keeping' or 'impression management' (van Dijk, 2004) and 'negative other representation or semantic macro-strategy of derogation regarding out-groups, that is, their division between 'good' and 'bad', superior and inferior, US and THEM. Van Dijk (2004) introduces these two major strategies in the form of an 'ideological square':

\author{
Emphasize Our good things \\ Emphasize Their bad things \\ De-emphasize Our bad things \\ De-emphasize Their good things (van Dijk ibid, p. 18).
}


The two major strategies are materialized through 27 other discursive moves such as:

Authority: Mentioning authorities to support one's claims.

Categorization: Assigning people to different groups.

Consensus: Creating agreement and solidarity

Disclaimer: Presenting an idea as something positive and then rejecting it by the use of terms such as 'but' in the second sentence.

Evidentiality: Using hard facts to support one's ideas.

Hyperbole: A device for enhancing and exaggerating meaning.

Implication: Deducing or inferring implicit information.

Irony: Saying something and meaning something else.

Lexicalization: an overall ideological strategy for negative other-representation through the semantic features of the words.

National Self-Glorification: A device to create positive self-representation by glorifying one's country.

Number Game: Using numbers and statistics to appear credible.

Polarization: Categorizing people as belonging to US with good attributes and THEM with bad attributes.

Presupposition: The common shared knowledge between people or the ideas taken for granted in a proposition.

Vagueness: Creating uncertainty and ambiguity.

Victimization: Telling bad stories about people who do not belong to US.

Others are 'actor description', 'comparison, 'consensus' 'example'/'illustration', 'generalization' 'Us Them'.

In analysing the text, the above strategies will be explored.

\section{Methodology}

\subsection{Research Design - Qualitative}

The specific type of qualitative research method employed for the study is content analysis. The study is exploratory in nature so the content of the text was analysed and the findings described.

\subsection{The Data and Data Source}

The text used in this study is the 2018 state of the nation address of president Nana Addo. The speech under study was obtained from www.myjoyonline.com, one of the official websites of the Multimedia Group Limited.

\subsection{Sampling and Procedure for data Analysis}

The study used the convenience sampling technique to select Nana Addo's state of the nation address. The choice has no political underpinnings. It was accessible and retrievable at the time. 
The text is analysed using van Dijk's (2004) ideological analytical strategies. The study uses CDA to determine the ideological strategies that are employed in the speech. The results are then categorised and analysed. The study applied the interpretative content analysis to investigate the communicative functions and ideological underpinnings of the linguistic choices made in the address.

\subsection{Procedure of Data Analysis}

The initial step which was carried out was a thorough reading of the speech to become well accustomed to it so as to see the discursive construction of ideology enacted through the linguistic choices. The data was then parsed into the various ideological strategies following van Dijk's 2004 ideological strategies. The various ideological strategies were identified and isolated. Recurrent patterns were counted and their percentage distribution was calculated using tables. This was followed by a critical description and analysis of the strategies to determine the underlying ideological strategies employed in the speech.

\subsection{Analysis of Data}

\subsubsection{Ideological Strategies in the Text}

The data has been analysed guided by van Dijk's 2004 ideological strategies. The main ideological strategies used in the address have been positive self-representation for President Nana Addo and his government and negative other representation for past opposition governments. In the address, positive self-representation has been tied up with negative other representation. The two major strategies are manifested in the speech through the use of some frequent minor ideological strategies; polarisation, evidentiality, number game, hyperbole, and citing of authority.

In the data, Nana Addo emphasises the good things his government is doing in all sectors of government as opposed to how badly the previous government(s) performed through the use of minor ideological strategies. The discursive moves expressed in table 1 below show his government's performance in the area of education, the economy, health, agriculture as well as better standards of living among Ghanaians.

The following table presents the frequent minor ideological strategies and themes in the address representing positive self-representation and negative other representation.

Table 1: Frequent Ideological Strategies and Themes in the Address

\begin{tabular}{|l|l|l|c|c|}
\hline $\begin{array}{l}\text { Discursive } \\
\text { Moves } \\
\text { (Minor I.S) }\end{array}$ & Themes & $\begin{array}{l}\text { Major Strategy } \\
\text { Major I.S) }\end{array}$ & $\begin{array}{c}\text { Number of } \\
\text { Occurrences }\end{array}$ & $\begin{array}{c}\text { Percentage } \\
\%\end{array}$ \\
\hline polarisation & $\begin{array}{l}\text { Economy 7 } \\
\text { Health 4 } \\
\text { Agriculture 6 } \\
\text { Infrastructure 6 }\end{array}$ & $\begin{array}{l}\text { Positive self-representation/ } \\
\text { Negative other representation }\end{array}$ & 23 & 33.3 \\
\hline Number game & $\begin{array}{l}\text { Economy 7 } \\
\text { Education 6 } \\
\text { Infrastructure 6 }\end{array}$ & $\begin{array}{l}\text { Positive self-representation/ } \\
\text { Negative other representation }\end{array}$ & 19 & 27.5 \\
\hline
\end{tabular}


Cynthia Logogye

IDEOLOGY AND POLITICAL DISCOURSE: A CRITICAL DISCOURSEANALYSIS OF

PRESIDENT NANA AKUFFO ADDO'S 2018 STATE OF THE NATION ADDRESS

\begin{tabular}{|l|l|l|c|c|}
\hline \hline Evidentiality & $\begin{array}{l}\text { Education 3 } \\
\text { Economy 5 } \\
\text { Unveiling future } \\
\text { plans 4 } \\
\text { Agriculture 4 } \\
\text { Infrastructure 4 }\end{array}$ & $\begin{array}{l}\text { Positive self-representation/ } \\
\text { Negative other representation }\end{array}$ & 20 & 28.9 \\
\hline Authority & Economy 3 & Positive self-representation & 3 & 4.3 \\
\hline Hyperbole & Economy 4 & $\begin{array}{l}\text { Positive self-representation/ } \\
\text { Negative other representation }\end{array}$ & 4 & 6 \\
\hline Total & & & 69 & 100 \\
\hline
\end{tabular}

Note: I. S.: Ideological strategy.

The various ideological strategies presented in the table above are employed in the address to express a positive self-representation of Nana Addo and his government as against negative other presentation of past governments. Each strategy will be elaborated on with some concrete examples and to show how the president through minor strategies engages in positive selfrepresentation as against negative other representation in the speech. In so doing along with van Dijk's 2004 ideological strategies, other techniques such as CDA are also, drawn upon. The work discusses the moves with evidence from the SONA.

From Table 1 above, polarisation occurred the most with a frequency of $33.3 \%$. The president employs this discursive strategy 7 times in the economy, 4 times in health, 6 times in agriculture, and 6 times in infrastructural development. He presents a positive image of his government in all those sectors of government and at the same time presents a negative image of past opposition governments. The various themes in the address are discussed under the discursive moves below.

\subsection{Polarisation}

In the speech, the president employs the strategy of polarisation and makes a positive selfrepresentation of his government and negative other representation of past governments in talking about the economy, health, agriculture, and infrastructure. Nana Addo adopts this strategy to show that he has the right and competent men for the job in all those sectors. Through the ideological strategy of polarisation, he presents himself as a leader who appreciates the efforts of members of his government and gives credit where it is due.

In talking about the economy, he does not take the credit alone but is quick to acknowledge team players for successes chalked. He shows how competent his team is in solving the nation's economic problems showing 'our good things' and 'their bad things'. He commends his vice president and finance minister for making giant strides in the economy. The following excerpts clearly show how previous governments have failed and how his administration has the men to do the job emphasising our good things and de-emphasising their good things.

"I am glad to be able to report that the Economic Management Team, under the stellar leadership of the strong, brilliant economist, Vice President Mahamudu Bawumia, has risen to the challenge, 
and the hard work is beginning to show positive results. Our economists have found imaginative ways to deal with the oppressive debt situation. Ken Ofori-Atta, the finance minister, is proving to be a national asset."

Nana Addo also employs polarisation as a strategy and emphasises his administration's good things at the same time de-emphasising the good things of past governments in talking about health. Nana Addo believes in 'a healthy people build a healthy nation'. In his speech about health, he criticises past governments for not making health a priority. His government, however, is going to act differently from those past governments.

He considers the health needs of the nation very important and therefore does not want to compromise health as past governments did. The following exemplifies the point,

"We have cleared a substantial part of the debts and arrears that were choking the National Health Insurance Scheme, courtesy of the prudent management of the able chartered accountant, Health Minister Hon. Kwaku Agyemang Manu, MP for Dormaa Central."

He emphasises his administration's good things hand in hand with the ideological strategy of polarisation, giving credit to his appointee and showing his good attributes and also how collaborative and competent his appointees are in helping him towards achieving his political agenda.

Furthermore, in the area of agriculture, the president makes use of polarisation, heaping praises on his appointees and announcing their good attributes and collaborative support. In so doing, he draws attention to how good he and his appointees are in tackling issues related to agriculture.

"That champion of Ghanaian farmers, the Minister for Food and Agriculture, Dr. Owusu Afriyie Akoto, is doing a yeoman's job."

From the above excerpt, Nana Addo undoubtedly announces how better his administration is performing than previous governments. He seeks to tell Ghanaians that he has good policies and he has the right and competent people, "emphasising our good things and deemphasising their good things". van Dijk (2004) considers those types of linguistic choices that seek to persuade and impress an audience as a key factor that determines the success of politicians reaching their goals and winning the public consensus in their quest for a continuous power struggle or to stay in power.

\subsection{Evidentiality}

Evidentiality is the second-highest discursive move deployed to present Nana Addo's government positively while painting a negative picture of past opposition governments in most sectors of government in the speech. Through this strategy, the president seeks to prove himself a credible leader. 
In the educational sector, Nana Addo seeks to show his credibility through the use of evidentiality, emphasising how his government is doing better in the field of education while painting a negative picture of past opposition governments.

The following exemplifies how Nana Addo emphasises the good things of his government in the field of education as against the bad things of past opposition governments,

\section{Mr. Speaker, we have restored teacher and nursing training allowances.}

2. To confound the sceptics and professional naysayers, we have implemented Free Senior High School education.

From the examples above, the president tells Ghanaians how his government has reversed some bad things done in the education sector by past governments as illustrated in example 1 'restored' and how in addition, his government has brought about new developments in that sector, the 'provision of free senior high school' as seen in example 2 above, hence emphasising the good things his government is doing in education as opposed to how badly the previous opposition government(s) performed. As part of his party's ideologies, Nana believes in education for all. During his campaign in 2016, he promised free education for all senior high school students. In the State of the Nation address, he talked about the implementation of free senior high school which his opponents thought was impossible, which now affords all needy students to go to school. This is considered a great feat the NPP government has achieved. Also, as part of his ideology of education for all, he has restored teacher and nursing trainee allowances to support needy students. The use of the word 'restored' clearly indicates something that was there, which had been taken away but has been brought back. The allowances were there but taken away by the previous opposition government, but his administration has brought it back. This emphasises his government's good things and emphasises the bad things of the previous government. In extracts 1 and 2 above, through the ideological strategy of evidentiality, the president has succeeded in presenting a positive self-representation for himself and his government and negative other representation.

The president also employs evidentiality to express positive self-representation and negative other representation in talking about the economic sector. He makes use of evidentials to prove himself a man of his words. According to President Nana Addo, when he promises, he delivers. He, therefore, presents himself as credible with evidence. See extracts 1 and 2 below,

1. "I made some brave predictions. I said we would "reduce significantly the budget deficit", and I said that, at the same time, we would grow and expand the economy. We have reduced taxes."

2. "We have doubled the capitation grant."

Extracts, 1 and 2 above provide evidence of credibility on the part of Nana Addo. The vocabularies that bring out the evidence of credibility in the address are 'reduced' and 'doubled'. This implied that the budget deficit was high, the economy was underdeveloped, and taxes were high. Through the strategy of evidentiality, Nana Addo presents a 'positive-self representation' of 
his government and subtly a negative other-representation. He shows how his government is improving the lives of Ghanaians by doubling the capitation grant, unlike the previous governments.

The capitation grant was inadequate prior to his party coming to power portraying the past government in a bad light. Before the coming of his party into power, all those areas of the economy had been mismanaged.

Nana Addo further engages in the use of evidentiality when he unveils plans for future development. The second part of the speech is dedicated to future plans, the adoption of good policies for future development. Going forward, Nana Addo anticipates several developmental projects including roads and railways, health, education, the economy, power/energy and industry, better living conditions, projects, technology, agriculture, etc. He considers those policies as the best. Through the strategy of evidentiality, Nana Addo engages in emphasising our good things, showing how his party is leading the nation to greater heights at the same time, he emphasises the bad things of previous governments in the development of roads.

In talking about plans to develop roads and railways, he engages in our good things, their bad things; he appears hard-hitting and he gives the clue that he is referring to the immediate past government, now in opposition.

"Mr Speaker, we have to build the roads to open up and link up the various parts of the country. ...It is a shame that, some seven years or so after work had started on the Eastern Corridor roads, we are nowhere near completion."

In the area of railway development, whereas past governments only paid lip service to the building of railways, bridging the northern and southern part of the country including neighbouring Burkina Faso, his administration is committed to bringing this dream to a reality unlike the past governments thereby emphasising our good things, de-emphasising their good things. The following extract illustrates the point,

"Mr Speaker, I know I am not saying anything new exactly; every government has said it, and it has been in every plan we have drawn up in this country since independence. But the difference this time is that we have started, and the dream of a modern railway network in our country will become a reality during the tenure of this administration."

To sound more credible, Nana employs evidentiality to convince his listeners that his administration is different from past administrations in infrastructural development.

"There is already a contractor on site for the construction of the Kojokrom to Manso section of the Takoradi to Kumasi rail line."

The extract above supports Chimbarange, Takavarasha, and Kombe (2014) position that the main aim of politicians is to persuade their audience of the validity of their political claims. 
Nana Addo, therefore, employs the ideological strategy of evidentiality to convince the nation that his government is committed to its promises unlike the past governments thereby painting a positive self-representation and negative other representation.

Also, in the area of agriculture, Nana Addo holds the ideology that agriculture forms the backbone of the country. He also believes that the future of Ghana lies in the promotion of agriculture. He, therefore, seeks to implement his proposed one-village-one-dam policy which was part of his manifesto intended to aid irrigation farming.

In the speech, Nana Addo showed his enthusiasm towards the promotion of agriculture through evidentiality and dealt a hard blow on past governments for how poorly they have performed in the agricultural sector and bemoaned their failure to pay serious attention to agriculture emphasising their bad things whilst emphasising his government's good things. He presents the following as evidence of his commitment to agriculture.

"For generations, we have bemoaned Ghana's reliance solely on rain-fed agriculture. It is a disgrace that we have had to rely on our Sahelian neighbours to make up the deficit in foods, such as vegetables."

To appear faithful about his enthusiasm in agriculture, he employs evidentiality to sound convincing to the citizenry.

"Our farmers can see that the government is putting resources to back up the usual words. The $50 \%$ subsidy on fertilizer, and the increase in the provision of extension services, are making a great difference to the performance of Ghanaian agriculture."

From the speech, Nana Addo is not only interested in agriculture but also aquaculture. He again emphasises his good things and de-emphasises their good things. He also talks about how the past governments have failed in this area too and how he has the best policies and men to solve the problem.

"The fishing harvest has gone down dramatically, and we have had to depend more and more on imported fish. We have started work to tackle these problems."

To sound more credible, Nana Addo employs an evidential hand-in-hand with polarisation to authenticate the truth value of his propositions.

"We have identified 100 dams in five regions across the country - Upper East, Upper West, Northern, Volta and Western - and stocked them with fingerlings. This is the start of big things to come, due to the efforts of the forceful Minister for Fisheries and Aquaculture, Hon. Elizabeth Afoley Quaye, MP for Krowor." 
By this, the president proves himself an honest leader while giving honour where honour is due and indirectly motivates his appointees to do more.

The president again employs evidentiality hand-in-hand with polarisation to appear credible and competent in tackling infrastructural problems in the country.

As part of his quest to improve the living standards of Ghanaians, he talks about certain infrastructural developments such as the provision of basic needs which according to him in the speech, governments since independence have ignored. See extracts 1-3 below,

1. "Sixty years after independence, the least we can, and should, do is to make sure that every Ghanaian has access to water and toilet facilities."

2. "We have begun the difficult process of making housing affordable for Ghanaians. Government, last year, abolished the 5\% VAT/NHIL on real estate sales, and continues to create a conducive environment that is reducing interest rates on mortgage loans."

3. "The acute accommodation problems that face our Armed Forces must be, and are now being tackled by that energetic Minister for Defence, Hon. Dominic Nitiwul, MP for Bimbilla."

To emphasise his party's good things and de-emphasise the good things of previous governments, Nana Addo provides evidence through linguistic choices and seeks to let Ghanaians see the intensity of the disservice past governments have done to the nation. He tries to influence the mental models, knowledge, attitudes, and eventually even the ideologies of recipients using language as attested by Van Dijk (1993).

In the extracts above, Nana Addo does not only engage the ideological strategy of evidentiality but also polarisation aimed at a positive self-representation and negative other representation. Through this strategy, he shows the poor performance of past governments while inspiring the hope of Ghanaians in his own government. For example, 'sixty years after independence...., 'Government, last year, abolished the 5\% VAT/NHIL on real estate sales.' He then goes on to heap praises on his appointee, minister for a good work done showing that he has the right men for the job.

Through evidentiality and polarisation, Nana Addo further portrays himself as a leader concerned about his people even in their pension as opposed to how past governments have treated pensioners.

"Mr. Speaker, thanks to the diligence of the hardworking Minister for Employment and Labour Relations, Hon. Ignatius Baffuor Awuah, MP for Sunyani West, we have been able to transfer some GH\$3.1 billion of Tier 2 pension funds into the custodial accounts of the pension schemes of the labour unions, funds that have been outstanding for six years, and about which the labour unions had been loudly complaining."

Here, the president again gives a direct clue as to which particular government's bad things he emphasises, "...funds that have been outstanding for six years". This directly refers to the immediate past government which is now in opposition. 


\subsection{Number Game}

The ideological strategy of number game is also employed in the SONA in making a positiveself representation and negative other representation. The speech abounds with numbers and statistics to make the president appear credible in his governance especially in the area of the economy. The following extract clarifies the point,

"Economic growth is increasing, from the alarming 3.6\% at December 2016, to 7.9\% in our first year. We have, nevertheless, been able to meet my promise made last year to the House, and reduced the fiscal deficit from $9.3 \%$, to an estimated $5.6 \%$ of GDP. The annual average rate of debt accumulation, which, in recent years, has been as high as 36\%, has declined to $13.6 \%$, as at September 2017. As a result, the public debt stock as a ratio of GDP is $68.3 \%$, against the annual target of $71 \%$ for 2017 , and end 2016 actual figure of $73.1 \%$."

These statistics enable the president to present his government in a positive light while presenting the past administration in negative other-representation showing their bad things and how inefficient they were as compared to his government. We see this typified in the linguistic choices in the extract above, Economic growth is increasing, from an alarming 3.6\% in December 2016, to $7.9 \%$ in our first year. We have.... reduced the fiscal deficit from $9.3 \%$ to an estimated $5.6 \%$ of GDP. The annual average rate of debt accumulation....has declined to $13.6 \%$... With these figures coupled with words such as growth is increasing, alarming, reduced fiscal deficit, debt declined, Nana Addo seems to suggest that his government is leading the nation in the right direction. Nana Addo attributes all these successes to the adoption of appropriate policies, and the normalisation of the power situation in the country under his government which the previous government failed to do. This strategy adopted by Nana Addo corroborates Van Dijk's (1993) assertion that political leaders try to influence the mental models, knowledge, attitudes, and eventually even the ideologies of recipients using language.

Again, the president engages in number game to show how faithful he is in his promises and to prove that his government has made great achievements indeed. He, therefore, quotes figures in order to appear credible. This statement is considered emphatic to buttress his statistics in the address, "as my old Mathematics teacher and, I suspect, everybody else's Mathematics teacher would say, you cannot argue with figures." The president's speech is therefore dominated by numbers and statistics in his bid to convince the nation of his government's credibility. See the extract below,

"As I promised, our economists have found imaginative ways to deal with the oppressive debt situation. This has brought some relief, and the annual average rate of debt accumulation, which, in recent years, has been as high as 36\%, has declined to 13.6\%, as at September 2017. Earlier, in January, the World Bank stated that Ghana's economy would probably grow by $8.3 \%$ this year, which would make it the fastest growing economy in the world." 
In quoting the figures above, Nana, however, appears hyperbolical; an ideological strategy adopted by politicians to sound convincing to the populace. The figures in the extract above show exaggeration. Typically, the word 'fasters' in the extract shows exaggeration; Nana Addo seems to be exaggerating when he talks about the likelihood of Ghana's economy becoming the fastest economy in the world.

Again, the president engages in number game hand in hand with polarisation to appear credible in talking about better living conditions. As part of his beliefs that it is not possible to argue with figures, he quotes figures to silence sceptics and critics. See the following extract,

"Mr. Speaker, thanks to the diligence of the hardworking Minister for Employment and Labour Relations, Hon. Ignatius Baffuor Awuah, MP for Sunyani West, we have been able to transfer some GH\$3.1 billion of Tier 2 pension funds into the custodial accounts of the pension schemes of the labour unions."

He employs polarisation to credit the achievement to the source, his minister for employment and labour relations. This way, he seems to be pointing to a witness to ascertain the truth value of the claims he makes and thereby appear more credible.

\subsection{Citing Authority}

Yet another ideological strategy adopted in the speech in a bid to convince the populace about the improvement of the economy is, citing authorities as stipulated by (van Dijk 2004). This strategy is adopted to back claims and projections made in the address for the president to appear credible. The citing of authority has been deployed aimed at persuading the audience of the validity of the president's claims of Ghana's economic strides under his governance. Authority is cited to back claims of how the economy is progressing of which the world is taking notice of. According to Jones and Peccei (2004), politicians throughout the ages have achieved success thanks to their "skilful use of rhetoric", by which they aim to persuade their audience of the validity of their views. The following illustrates the point,

"Earlier, in January, the World Bank stated that Ghana's economy would probably grow by 8.3\% this year, which would make it the fastest-growing economy in the world. last week, Bloomberg described Ghana's Stock Exchange as the best-performing Stock Exchange in the world for January 2018."

In the extract above, Nana Addo goes beyond positive self-representation and negative-other representation of previous governments in Ghana to the outside world. Aside from the use of authority to support his claims, Nana Addo employs hyperbole and projects Ghana's economy over other economies in the world. According to him, in the address, Ghana's economy under him is growing ahead of other economies such as Nigeria, Brazil, and even China within the space of two years after he assumed power, and this in my view is a hyperbolical, and only meant to emphasise his positive self. Typical hyperbolical expressions in the extracts above are, ...fastest 
growing economy in the world, ... the best-performing Stock Exchange in the world. However, one does not begrudge his projections and high opinion of his country as he does it as a politician and to appear a good leader in the eyes of electorates to score a political point.

In political discourse, as a type of persuasive discourse, politicians are in the business of selling their products - their policies and their points of view, which they consider as "truth" (Vukovic, 2014). Donna, however, sees these as techniques of discursive manipulation used by those who would want to obtain and retain political, social, and economic power (Donna 2006).

\subsection{Hyperbole}

In talking about infrastructural development, the president is of the idea that he can build a Ghana beyond aid, unlike the previous governments.

\section{"We will build a Ghana Beyond Aid."}

One is not in any way trying to be sceptical, but I see this as hyperbole, as no one or nation is self-sufficient. At a point in time, we all need one thing or the other from others. Ghana's first president, Dr. Kwame Nkrumah held a similar ideology. He is quoted to have said, "the black man is capable of managing his own affairs" but more than sixty years down the line, the nation still depends on foreign aid. Nana Addo employs this hyperbolical ideological strategy to persuade the people that he is a capable leader with the ability to lead an aid-free country in order to gain the support of the nation and to maintain and control political power.

In the speech, however, Nana Addo somehow makes a deviation from van Dijk's (2004) ideological strategies where he de-emphasises his own government's good things; he acknowledges that he could not fulfil a promise he has made, a part, I found rather unusual of a politician. For example,

"I promised last year we would endeavour to pass into law the Affirmative Action Bill. This did not happen."

With this, Nana Addo presents an ideology of genuine politicking, unlike some politicians who might try to cover that up. He tries to present himself as a genuine politician in the eyes of the people. He holds the idea that politicians are human beings and therefore sometimes may be incapable of performing certain things they had wished to perform.

Nana Addo also went out of the norm to praise or emphasise the good things of past leaders, projecting a positive-other-presentation rather than a negative-other presentation as typical of politicians.

"I organised, on that day, an inter-faith religious ceremony of thanksgiving to Almighty God, graced by the presence of my three predecessors, their Excellencies the $1^{1 \text { tt }}, 2^{\text {nd }}$ and $4^{\text {th }}$ Presidents of the $4^{\text {th }}$ Republic, Jerry John Rawlings, John Agyekum Kufuor, and John Dramani Mahama." 
From the above extract, Nana Addo expressed his joy in having past presidents accept to attend a programme he invited them to. He tries to present his personal ideology that when people do well irrespective of their political affiliation, it should be acknowledged and they should be commended. He does this to appear an honourable leader who even acknowledges the good of his opponents.

\section{Conclusion}

The study has discovered that the macro strategies of 'positive self-representation and 'negative other- representation' are intimately tied up with 'Polarization' of in-group versus out-group ideologies or US-THEM plus other minor ideological strategies as evidentiality, number game, hyperbole as well as citing authority. The frequent minor ideological strategy has been polarisation. The president holds the idea that people must be commended for their good works. $\mathrm{He}$, therefore, commends his appointees for their collaborative efforts which have brought great relief to Ghanaians, and tries to motivate them to do more while projecting past opponent governments negatively. He also employed evidentiality and number game to appear truthful, he has the perception that people cannot argue with numbers but according to Vukovic (2006), there is no absolute truth in politics. Truth is relative as far as political discourse is concerned. He also cites authority to appear credible in his achievements. He does this to persuade and impress his audience as well as gain their trust in his administration to maintain and control power.

Overall, the results showed that the SONA is rather used as a medium for the president to sell his ideologies more than performing informative functions. In that regard, in the address, language is used not only as a means of communication but also as an instrument of persuasion, power, and control.

This shows that politicians will use any means possible to sell their political agenda. According to Jones and Peccei (2004), politicians throughout the ages have achieved success thanks to their "skilful use of rhetoric", by which they aim to persuade their audience of the validity of their views through delicate and careful use of elegant and persuasive language.

However, Nana Addo somehow makes a deviation from van Dijk's ideological postulates at some point in the speech where he de-emphasises his own government's good things; he acknowledges that he could not fulfil a promise he has made, a part, I found rather unusual of a politician. He also admitted in another one occurrence where past governments before his government did creditably well. With these, Nana Addo appears to paint an image of honesty on himself as part of his ideological strategies.

\section{Conflict of Interest Statement}

The author declares no conflict of interest. 


\begin{abstract}
About the Author
Cynthia Logogye is a lecturer at the Department of English Education, University of Education, Winneba. She is a PhD candidate at the University of Cape Coast, Ghana. She has published research papers in referred academic journals. Her research interest is discourse analysis, in recent times, political discourse.
\end{abstract}

\title{
References
}

Bayram, F. (2010). Ideology and political discourse: A critical discourse analysis of Erdogan's political speech. ARECLS, 7, 23- 40.

Chilton, P. (1988). Orwellian Language and the Media. London: Pluto Press.

Chilton, P. (2005). Language and the nuclear arms debate: Nukespeak today. London: Pinter.

Chilton, P. (2005). Missing links in mainstream CDA: In A new agenda in critical discourse Netherland: John Benjamins Publication.

Edu-Buandoh, D. F., \& Ahialey, H. O. (2012). Exploring the ideological implications of questions in elicitation in courtroom cross-examination discourse in Ghana. Language Discourse and Society, 11, 11-30.

Fairclough, N. (1985). Critical and descriptive goals in discourse analysis. Journal of Pragmatics, 9, 739-763.

Fairclough, N. (1989). Language and power. London: Longman.

Fairclough, N. (1992). Critical Language Awareness. London: Longman

Fairclough, N. (1995). Critical discourse analysis: The critical study of language. New York: Longman.

Fairclough, N. (1995). Media Discourse. London: Edward Arnold.

Fairclough, N. (1999). Linguistic and Intertextual Analysis within Discourse Reader. Analysis.

Fairclough, N. (2001). Language and Power (2nd. ed.). London: Longman.

Fowler, R., Hodge, R., Kress, G., \& Trew, T. (1979). Language and Control. London: Routledge and Kegan Paul

Hamilton, H. E. (ed), The handbook of discourse analysis. Oxford: Blackwell, pp. 352-371.

van Dijk, T. A. (2006). 'Politics, ideology, and discourse', in Brown, K.(ed), The Encyclopedia of language and linguistics. Oxford ; New York: Pergamon Press. 9, 728-740.

Kantanka K. S. (2016). Questioning and debating in UK and Ghanaian parliamentary discourse. Unpublished dissertation, University of Leeds, UK.

Kantanka K. S. (2018). Questioning design and the rules of questioning in UK prime ministers' questions and Ghanaian ministers' questions. Abibsem: Journal of African Culture and Civilisation. 7, 51-88.

Kress, G. (1985). Ideological structures in discourse. In T. A. van Dijk, Handbook of discourse analysis (pp. 27-42). New York: Academic Press.

Kress, G., \& Trew, A. (1978). Ideological transformations of discourse. Sociological Review, 26(4), 755-776. 
Sharndama, E. C. (2015). Political discourse: a critical discourse analysis of president Muhammadu Buhari's inaugural speech. European Journal of English Language and Linguistics Research 3 (3) 12-24

Van Dijk, T. A. (1993). Principles of critical discourse analysis. Discourse and Society, 4(2), 24983.

Van Dijk, T. A. (2000). Discourse analysis as ideology analysis. Available at http://www.daneprairie.com.

van Dijk, T. A. (2003). 'Critical discourse analysis', in Schiffrin, D., Tannen, D., Rashidi, N. and Souzandehfar, M. (2010). A Critical Discourse Analysis of The Debates Between Republicans and Democrats Over the Continuation Of War In Iraq. Retrieved from https://www.researchgate.net/publication/266492249 A critical discourse analysis of $t$ he debates between Republicans and Democrats over the continuation of war in I $\underline{\mathrm{raq}}$

Wang, J. (2010). A critical discourse analysis of Barak Obama's speeches. Journal of Language Teaching and Research, 1(3), 254-261.

Wodak, R. (1995). Handbook of Pragmatics. Amsterdam/Philadelphia.

Wodak, R. (2002). Aspects of critical discourse analysis. ZFAL, 36, 5-31.

Wodak, R. (2002). Friend or foe: the defamation or legitimate and necessary criticism? Reflections on recent political discourse in Austria. Language and Communication, 22, 495517.

Wang, J. (2010). A critical discourse analysis of Barack Obama's speeches. Journal of Language Teaching and Research. 1(3), 254-261. 
Author(s) will retain the copyright of their published articles agreeing that a Creative Commons Attribution 4.0 International License (CC BY 4.0) terms will be applied to their work. Under the terms of this license, no permission is required from the author(s) or publisher for members of the community to copy, distribute, transmit or adapt the article content, providing a proper, prominent and unambiguous attribution to the authors in a manner that makes clear that the materials are being reused under permission of a Creative Commons License. Views, opinions and conclusions expressed in this research article are views, opinions and conclusions of the author(s). and European Journal of Literature, Language and Linguistics Studies shall not be responsible or answerable for any loss, damage or liability caused in relation to/arising out of conflicts of interest, copyright violations and inappropriate or inaccurate use of any kind content related or integrated into the research work. All the published works are meeting the Open Access Publishing requirements and can be freely accessed, shared, modified, distributed and used in educational, commercial and non-commercial purposes under a Creative Commons Attribution 4.0 International License (CC BY 4.0). 